\title{
Innovation and Investment Role in Interaction of Small Business in Criteria Analysis of University Complexes' Efficiency
}

\author{
Victoria S. Telyatnikova \\ Volgograd State Socio-Pedagogical University \\ Volgograd, Russia \\ vika.t@list.ru
}

\author{
Anna.V. Shokhnekh \\ Volgograd State Socio-Pedagogical University \\ Volgograd, Russia \\ shokhnekh@yandex.ru
}

\author{
Natalia S. Mushketova \\ Volgograd State University \\ Volgograd, Russia \\ nmushketova@yandex.ru
}

\begin{abstract}
A study of the innovation and investment role in interaction of small businesses confirms that human resources are not ready for performing business. Solving problems in the process of building competencies in professional and entrepreneurial activities requires a new approach to higher education at the university. The need to create a platform for university complexes involves increasing personal competencies of human resources. These are both entities that determine the needs of consumers and units that participate in the economic chain of meeting the needs of society in the form of small business. The article presents: criteria of the university complexes' efficiency; parameters of innovation and investment role in interaction of small business in a criteria analysis of the university complexes' efficiency; a matrix of expert assessments of the university complexes' efficiency according to the parameters of innovation and investment role in interaction of small business.
\end{abstract}

Keywords: innovation, investment, role, small business, criteria, analysis, university complexes' efficiency

\section{INTRODUCTION}

Nowadays it makes sense to form a platform of university complexes from the perspective of studying the parameters of innovation and investment role in interaction of small business. Small business as a form of self-employment and an alternative to wage labor is a platform for increasing future personal competencies. The relevance of the formation of future personal competencies is manifested in the transition to a new technological structure taking into account modern trends in sustainable development. The lack of favorable conditions for the identification and implementation of new professions in education is becoming a fundamental problem.
Sustainable development, announced in 1987 by G.Kh. Brutland at the UN General Assembly, is necessary for economic growth of economic systems without environmental destruction and ecosystem imbalance [5].

For a younger generation the perception of innovation and investment activity due to sustainable development becomes relevant as «long-term continuous development that meets the needs of people living today without compromising the needs of future generations.» [16]. In this concept sustainability routes change in the way of environmental, social and economic development $[10,11,16]$.

This approach to sustainable development in the world involves exploring the paradigm of personal growth, and, therefore, the formation of a new concept in the field of education.

Currently, the key problems occur in terms of providing staff for future requests of society for new professions, which suggests answering a number of important questions such as Who should we teach? What to teach? For whom to teach? What is the sphere for performing the competencies?

These issues are reinforced by the transition of the global community to the digital economy. The digital economy has been determined under the pressure of modern trends in the widespread use of electronic-digital communication and innovative technologies in all business processes. In July 2017 
educational competencies. Primary competencies also allow the formation of human capital as an intellectual resource. At present, an intellectual resource is rightly regarded as an economic indicator.

\section{RESUlts}

All of the above already implies the contribution of global and national government investments to intangible assets of the world community. Intangible assets such as intellectual property will allow in the future to form high innovative technologies for the development of the digital economy in all spheres of society.

The criteria for the efficiency of university complexes are presented in Figure 1. in the formation of competencies in professional and entrepreneurial activities require a new approach to higher education at the university. It should be stated that today the problems in the formation of competencies in professional and entrepreneurial activities are not resolved on the basis of the supporting university $[2,4,5,8]$.

The study shows the selection of only one supporting university in the region. It means there is only one "boiling point" is being created in the region in the process of scientific and practical research. It will not allow fulfilling all the parameters necessary for the formation of new concepts for effective innovation and investment role interaction of small businesses [1, 3, 14, 15].

The formation of a platform for the effective interaction of universities as a target conglomerate in the training of the future personnel is determined by the institutional approach [9, 13, 15]. The institutional approach is currently being effectively applied in science and practice, based on the interaction of all sectors of the economy, including financial and non-financial sectors, government sector, households, non-profit organizations (for serving households) [7]. This is highly essential due to the integration of sustainable development and the digital economy.

\section{MATERIALS AND METHODS}

Comparative analysis is used for verification of the offered hypothesis. The direction of the institutional approach to the foresight development of university complexes determines the personnel policy paradigm for environmental, social and economic systems, which is aggravated by the conditions of the digital economy.

The expediency of the transition to a platform which suggests the effective interaction of university complexes is determined by the features of the educational process that combines social and economic areas [7, 12]. For innovation and investment design in small business there must be competent personnel who will be able to identify future demands of a digital and sustainable global and national community. Education should be a mechanism for the diverse interaction of universities from the point of perceiving rolebased interaction in the higher education system.

World and national education as a form of social activity of the state involves giving the young generation primary
Fig. 1. Efficiency criteria for university complexes

In a system like that one global and national education needs foresight development, or, as the authors suggest, Stephorizon Forecast. Step-horizon Forecast or literally «a step beyond the horizon visibility for forecasting the future involving building a model over a time interval of 20-30 years».

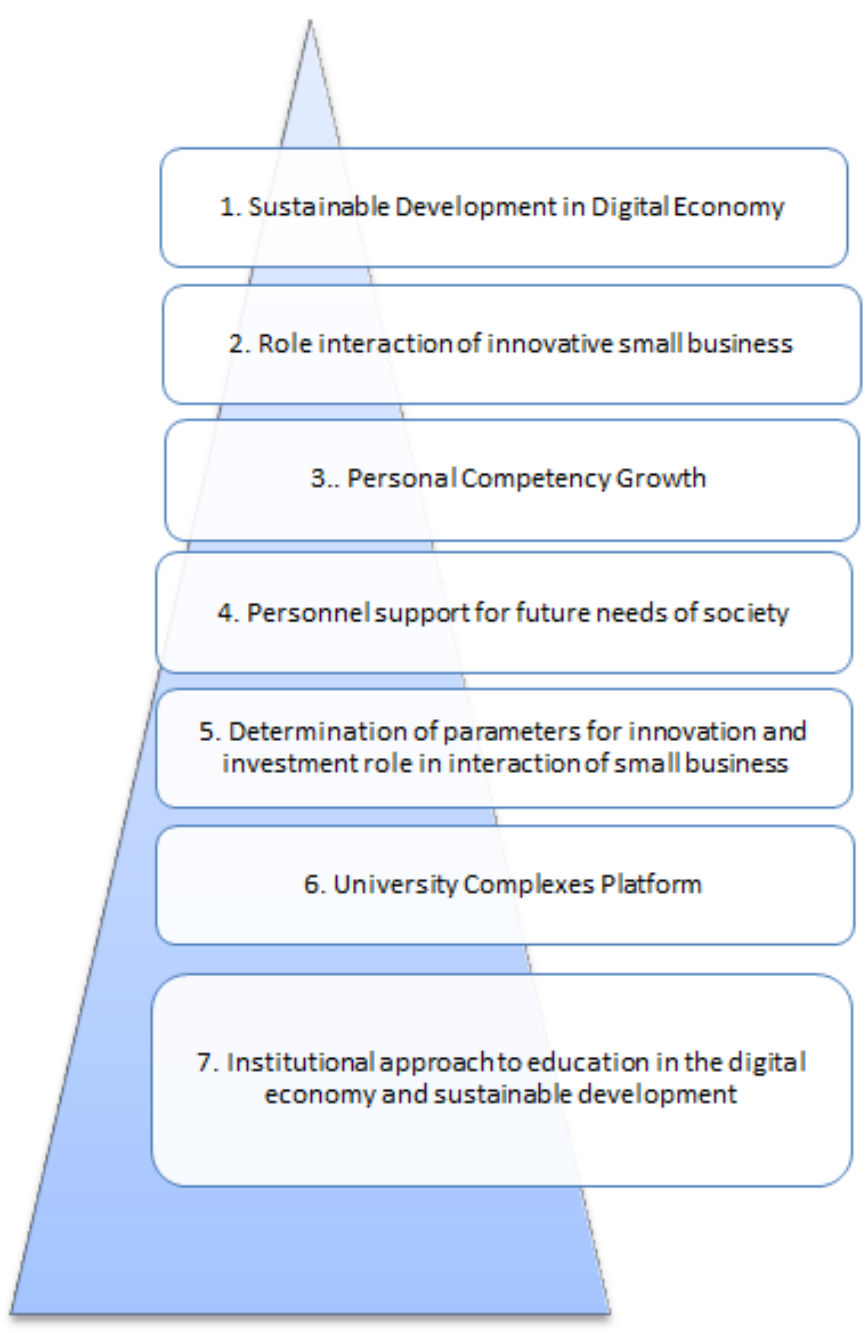


last control stage can be confirmed by patents, certificates and other documents ensuring the protection of intellectual property. The suitable model of the role interaction of small businesses is supervised on the platform of university complexes in the context of a real order for an innovative product.

Information management resource for the construction of scenarios Step-horizon Forecast in the topics of the educational process of regional development; the inclusion of disciplines that meet the requirements of regional development by industry; reassessment of the structure for design work; analysis of intersectional external and internal externalities; building a cognitive map of priority industries for the region; analysis of the level of energy conservation in the region; analysis of the depth level of regional resources processing; assessment of environmental protection of the regional work.

In this study we showed eight parameters of the innovation and investment role interaction of small business in the criteria analysis of the university complexes' efficiency which can be distinguished as X1 - world community's request for sustainable development; X2 - world community's request for the integration of business entities in the digital economy; X3 - world community's request for the formation of human capital as an intellectual resource; X4 - world community's request for Step-horizon Forecast in the preparation and implementation of the future in 20-30 years; X5 - world community's request for project thinking and project training; X6 - world community's request for a distance learning form; X7 - world community's request for team projects; X8 world community's request for the construction of scenarios Step-horizon Forecast in the topics of the educational process of the territory development (Figure 2).

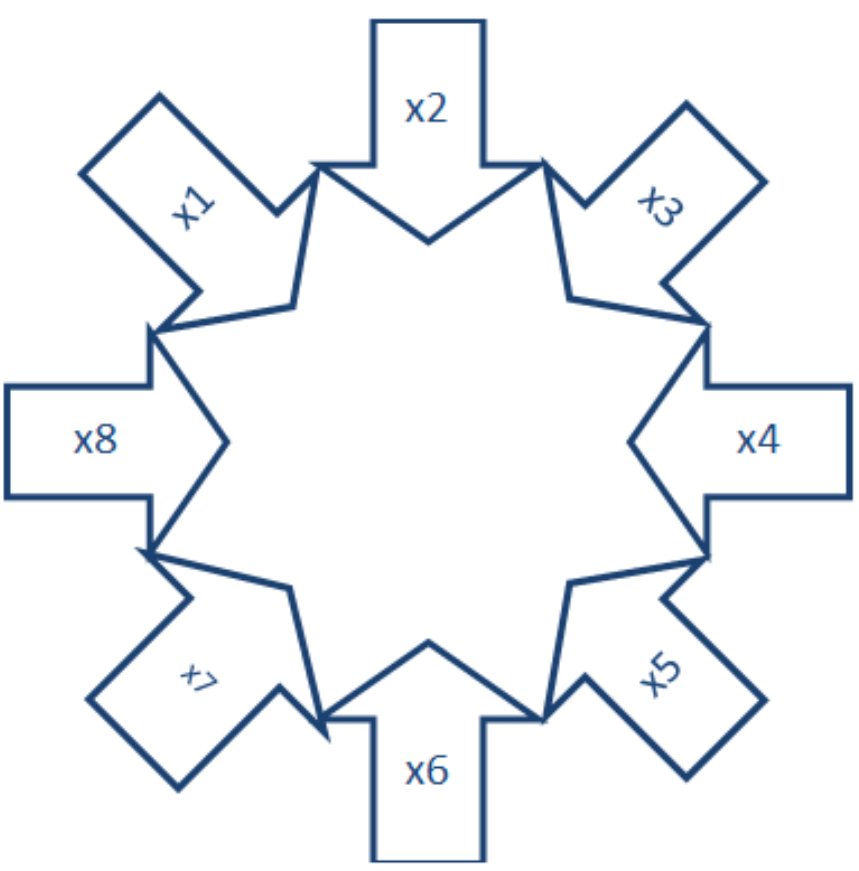

Fig. 2. Parameters of innovation and investment role in interaction of small business in a criteria analysis of the university complexes' efficiency
Team projects that can be implemented within two to three semesters can be laid on the site of university complexes. The
An effective university complex is presented as an automated platform that allows with the help of electronic communication tools to remotely practice the acquired competencies in key industry enterprises.

The criteria analysis of the university complexes' efficiency includes implemented micro, small, medium and large projects for entrepreneurial industry counterparties who are interested in making a profit based on the use of regional resources. The implementation of labor-barter exchange on the platform of university complexes with the participation of innovative small businesses will allow: 1) to ensure the innovative development of products by consumers on targeted requests oriented to their further commercial use; 2) target problems in the region and possible participation of small businesses with the possibility of dealing with them via projects; 3) to determine the necessary skills of project, scientific, research, organizational and managerial work of students from the perspective of a small business request.

The study shows trends in practice-oriented programs implemented on a laboratory basis of students' project activities. Training on the platform of the university complex should be performed with practical management tools from the problems of the customer to the organizational issues of building project work. 
The turbulent environment of the business environment is aimed at strengthening the innovation and investment role in interaction of small businesses in the context of sustainable development and digitalization. In disordered reality it is difficult to provide innovative and investment role in interaction of small businesses outside the platform of university complexes, relying on a rational basis only.

The development of a criteria analysis of university performance is functionally necessary for: 1) highlighting the role-playing interaction of small business in the region's infrastructure; 2 ) the vision of the role of human resources in the Step-horizon Forecast; 3) the formation and adjustment of small business development programs; 4) selection of target teams for specific projects and practical in terms of science employees, students, graduate students (table I).

TABLE I. A MATRIX OF EXPERT EVALUATIONS OF THE UNIVERSITY COMPLEXES' EFFICIENCY ACCORDING TO THE PARAMETERS OF INNOVATION AND INVESTMENT ROLE IN INTERACTION OF SMALL BUSINESS

\begin{tabular}{|c|c|c|c|c|c|c|c|c|c|}
\hline Categories & $\begin{array}{c}\mathrm{X} \\
\mathbf{1}\end{array}$ & $\begin{array}{l}X \\
2\end{array}$ & $\begin{array}{l}\mathbf{X} \\
\mathbf{3}\end{array}$ & $\begin{array}{l}X \\
\mathbf{4}\end{array}$ & $\mathrm{X5}$ & X6 & $\mathbf{X 7}$ & $\mathrm{X8}$ & $\begin{array}{l}\text { To } \\
\text { tal }\end{array}$ \\
\hline $\begin{array}{l}\text { 1. Sustainable } \\
\text { Development } \\
\text { in a Digital } \\
\text { Economy }\end{array}$ & + & + & + & + & + & + & + & + & 8 \\
\hline $\begin{array}{l}\text { 2.Role } \\
\text { interaction of } \\
\text { innovative } \\
\text { small business }\end{array}$ & + & + & + & + & + & + & + & + & 8 \\
\hline $\begin{array}{l}\text { 3. Personal } \\
\text { Competency } \\
\text { Growth }\end{array}$ & + & + & + & + & + & + & + & + & 8 \\
\hline $\begin{array}{l}\text { 4. Personnel } \\
\text { support for } \\
\text { future needs } \\
\text { of society }\end{array}$ & + & + & + & + & + & + & + & + & 8 \\
\hline $\begin{array}{l}5 . \\
\text { Determination } \\
\text { of parameters } \\
\text { for innovation } \\
\text { and } \\
\text { investment } \\
\text { role in } \\
\text { interaction of } \\
\text { small business }\end{array}$ & + & + & + & + & + & + & + & + & 8 \\
\hline $\begin{array}{l}\text { 6. University } \\
\text { Complexes } \\
\text { Platform }\end{array}$ & + & + & + & + & + & + & + & + & 8 \\
\hline $\begin{array}{l}\text { 7. Institutional } \\
\text { approach to } \\
\text { education in } \\
\text { the digital } \\
\text { economy and } \\
\text { sustainable } \\
\text { development }\end{array}$ & + & + & + & + & + & + & + & + & 8 \\
\hline Total & 7 & 7 & 7 & 7 & 7 & 7 & 7 & 7 & 56 \\
\hline
\end{tabular}

A matrix of expert assessments will help to identify effectiveness problems of the university complexes' platform according to the parameters of innovation and investment role in interaction of small businesses for subsequent adjustment.

Small business is assigned a key role as a driver of sustainable development, where for stable operation it is necessary: 1) to build the suitable Step-horizon Forecast model; 2) to design the stages of strategic achievement of the future model; 3) to identify and mitigate the risks of the process of building the model Step-horizon Forecast; 4) to build mechanisms that stimulate and encourage the achievement of established key arrays in the Step-horizon Forecast; 5) to identify, develop and apply mechanisms for the adaptation of entrepreneurs in the digital economy and sustainable development.

The Step-horizon Forecast human recourses policy is aimed at identifying new professions and new activities for small businesses, which will allow for a smooth transition to sustainable development in the context of the transition to the sixth technological structure and massive work with digital technologies in the future. The professions that will appear in the coming years in the high-tech sectors of world industry will develop and will require completely new competencies for the formation of personnel policies and new industries from small businesses.

\section{CONCLUSION}

In conclusion, it should be noted that the functional features of the university complexes' efficiency should be shown in the management of the competent development of a leader which includes: self-esteem and self-respect; selfefficacy and control; increase in the level of emotional intelligence. For small businesses, such personal characteristics form the personnel's disposition to an active or passive position of life goals. On the platform of university complexes a critera analysis of the efficiency of the innovation and investment role in interaction of small business in particular industry can be formed.

University complexes from the perspective of an institutional approach will identify professional externalities appearing in the interconnection of many industries. There is a tendency to complication and complexity of the activities of highly qualified specialists. Digital orientation and multidisciplinarity will determine the competitive advantages of personnel in the Step-horizon Forecast. Personnel competencies will quickly become obsolete due to the influence of digital technologies, which determines the revision of the model of modern education aimed at lifelong education throughout life. The digital educational environment is the Step-horizon Forecast of practice-oriented educational programs of personnel policy. The rate of change in the digital complexity of professional tasks is growing, therefore, professions for new types of small business activities and its role interaction in sustainable development, which seem fantastic, may become popular in the future.

The parameters of the innovation and investment role in interaction of small business in the criteria analysis of the effectiveness of university complexes on the Step-horizon Forecast personnel policy is presented as a map of possible directions for building your own motion paths into a model of the future. 
[9] Al. M. M. Y. Oudah, A. V. Shokhnekh, O. S. Glinskaya, M. I. Shokhnekh, and I. A. Chusov, "Regional mechanisms of modernization of infrastructure of regions and the country in the system of innovational development", In the book: Specifics of Decision Making in Modern Business Systems: Regularities and Tendencies Bingli, 2019, pp. 209-227.

[10] E. G. Popkova and B. S. Sergi, "Will Industry 4.0 and Other Innovations Impact Russia's Development?", In: Exploring the Future of Russia's Economy and Markets, Emerald Publishing, 2019, 3442 p.

[11] A. V. Shokhnekh, O. A. Mironova, F. F. Hanafeev, O. A. Kuzmenko, and L. F. Shilova, "Indicators of artificial intelligence of financial evaluation of small business investment attractiveness", Studies in Computational Intelligence, 2019,V. 826, pp. 1031-1041.

[12] A. V. Shokhnekh, G. I. Sidunova, and E. Yu. Naumova, "Information management resource of forsight development of university as a support of innovative site of the region of russia", In the collection: World scientific and technological trends in the socio-economic development of the agro-industrial complex and rural territories Materials of the International scientific-practical conference dedicated to the 75th anniversary of the end of the Battle of Stalingrad, 201, pp. $348-352$.

[13] A. V. Shokhnekh, V. S. Telyatnikova, V. L. Pozdeev, A. L. Nosov, and N. S. Mushketova, "Concept Strategy of Innovative Small Business in the System of Economic Security of the Digital Economy", Growth Poles of the Global Economy: Emergence, Changes and Future Perspectives, Series: Lecture Notes in Networks and Systems, Cham : Springer, 2020, V. 73, pp.1397-1406.

[14] G. I. Sidunova and A. V. Shokhnekh, "Balance-cognitive approach to foresight-development of management audit efficiency digital economic systems in the context of strategic drift", Lecture Notes in Networks and Systems, 2019, V. 57, pp. 657-665.

[15] V. S. Telyatnikova, A. V. Shokhnekh, V. I. Bespyatykh, M. A. Azarskaya, and O. Yu. Kolyshev, "Approaches to Formation of an Innovative Platform of University Complexes in the Strategy of Human Resources Development as Small Business Entrepreneurs" Growth Poles of the Global Economy: Emergence, Changes and Future Perspectives, Series: Lecture Notes in Networks and Systems, Cham : Springer, 2020, V. 73, pp. 1363-1372.

[16] O. K. Tsapieva, "Sustainable development of the region: theoretical foundations and model", Problems of the modern economy, 2010, no. 2, pp. 307-311 [Electronic resource]. Available at: https://cyberleninka.ru/article/v/ustoychivoe-razvitie-regionateoreticheskie-osnovy-i-model. 